\title{
Assessment of Total Petroleum Hydrocarbons Content of Soils Within Estate and Works Departments of Three Universities in Port Harcourt Housing Heavy-Duty Generators
}

\author{
EDORI Enize Simeon ${ }^{1 *}$, EDORI Onisogen Simeon ${ }^{2}$ and WODI Chizoba $\mathrm{T}^{3}$ \\ ${ }^{1}$ Post Graduate Student, Department of Chemistry, Ignatius Ajuru University of Education Rumuolumeni, Nigeria \\ ${ }^{2}$ Lecturer 1, Department of Chemistry, Ignatius Ajuru University of Education Rumuolumeni, Nigeria \\ ${ }^{3}$ Post Graduate Student, Department of Chemistry, Ignatius Ajuru University of Education Rumuolumeni, Nigeria \\ *Corresponding author: EDORI Enize Simeon, Post Graduate Student, Department of Chemistry, Ignatius Ajuru University \\ of Education Rumuolumeni, Nigeria
}

\section{ARTICLE INFO}

Received: 幽 August 27, 2020

Published: 幽 September 07, 2020

Citation: EDORI Enize Simeon, EDORI Onisogen Simeon, WODI Chizoba T. Assessment of Total Petroleum Hydrocarbons Content of Soils Within Estate and Works Departments of Three Universities in Port Harcourt Housing Heavy-Duty Generators. Biomed J Sci \& Tech Res 30(1)-2020. BJSTR. MS.ID.004894.

Keywords: Heavy-Duty Generators; Total Petroleum Hydrocarbons; Estate and Works;Pollution;Universities; Soil; Contamination

\begin{abstract}
Soil samples were collected at random from the Estate and Works Departments of three universities in Port Harcourt, Rivers State, Nigeria, where heavy-duty diesel generators are mounted to provide electricity for the universities environments and assessed for total petroleum hydrocarbons contamination. Soxhlet extraction method was used for the extraction of the total petroleum hydrocarbons and due clean-up of the chromatographic column followed. Total petroleum hydrocarbons were analyzed with Gas Chromatography-Flame ionization detector (GC-FID) to detect and quantify the levels in the different stations. The results obtained from the soil samples from the different universities were; IAUE, $1475.56904 \mathrm{mg} / \mathrm{Kg}$; RSU, $953.11949 \mathrm{mg} / \mathrm{Kg}$ and UNIPORT, $968.93886 \mathrm{mg} / \mathrm{Kg}$ with an average total petroleum hydrocarbons concentration of $1132.20913 \mathrm{mg} / \mathrm{Kg}$. Total petroleum hydrocarbons contamination levels obtained in the three stations were higher than the $50 \mathrm{mg} / \mathrm{Kg}$ limit allowed by DPR for agricultural soils. Source diagnostic ratios and indices used in analyzing the total petroleum hydrocarbons contamination revealed that the pollution was majorly due to anthropogenic origin, although other sources such as terrestrial vascular plants, biogenic origin also contributed. Since the contamination level of total petroleum hydrocarbons in the soils were greater than target limit, the universities should therefore provide remediation schemes at regular intervals to forestall any danger that it might pose to the workers in the departments.
\end{abstract}

Abbreviations: GC-FID: Gas Chromatography-Flame Ionization Detector; UNIPORT: University of Port Harcourt; RSU: Rivers State University; DPR: Department of Petroleum Resources; EGASPIN: Environmental Guidelines and Standards for the Petroleum Industries in Nigeria; LHC: Long Chain Hydrocarbons; SHC: Short Chain Hydrocarbons; ACL: Average Carbon Chain Length; CPI: Carbon Preference Index

\section{Short Communication}

The fundamental and non-replaceable nature of the soil which is a natural link between other natural components like the air and water together complete the environmental cycle. The interactions between these natural components of the environment has helped in providing the essential necessities of life like food, water, fuel and support for man and other living organisms [1]. The soil which is 
very important for the survival of life when contaminated or polluted by petroleum hydrocarbons poses serious effect and danger to the environment worldwide and hence attracts the attention of the public. One major way which petroleum hydrocarbons enter into the environment is by the activities of man, which is not properly checked, managed or controlled [2]. Agricultural and industrial activities discharge waste into the environment (air, water and soil) [3]. Total petroleum hydrocarbons are now the main organic pollutant in the soil. The presence of total petroleum hydrocarbons in the soil have negatively impacted on human health, growth and proper functioning of other organisms in the soil space.

Soil contamination by total petroleum hydrocarbons has both a long-term and a short-term side effect on the soil quality and the proper functioning as well as the quality of food produced from the affected soil $[1,4]$. The production of energy is associated with transformation of 9-petroleum products and other chemicals. The process of crude oil exploration to the time of final consumption can lead to severe environmental pollution that may become irreparable [5]. The different chemicals that are produced from crude oil, when present in the environment can lead to several health problems in clean-up workers, which include pulmonary disease, neurological irregularities, skin colour change and pregnancy related issues in women. The pollution occasioned by total petroleum hydrocarbons can have a long-term or a short-term effect on the environment [6], man and other creatures that inhabit the surrounding where pollution is being noticed. Spills from fuels and oils in the soil causes severe environmental damage and pollution that potentially threaten the ecosystem and human life. The effect of the contamination of crude oil on the soil has negative impact due to its flow from soil and water to man [7].

The resultant effect of soil pollution by total petroleum hydrocarbons include the deterioration of the physical, chemical and biochemical properties of the soil, limitation in the growth of plants, deficiency of oxygen and water, shortage of nitrogen and phosphorus-based nutrients in the soil $[7,8]$. Hydrocarbon pollution or contamination leads to increase in the acidic value and concentration level of heavy metals in the soil $[9,10]$. The effect of such pollution on the soil is achieved by initiating deviations from provisional values thereby resulting in negative environmental and health challenges. The use of such lands become limited due to total petroleum hydrocarbons contamination and therefore requires immediate remediation activities, which if not put in place may affect the groundwater, rivers and the surrounding environment, thereby causing more harm [11]. The contamination of the soil by hydrocarbons have a resultant effect on the $\mathrm{pH}$ value by lowering it and grossly affects agricultural and horticultural crop output by lowering production $[12,13]$.

The contamination/pollution of the site introduces different compounds into the soil which have differing chemical characteristics from the original mixture. The volatile components of the mixture easily evaporate while the heavier compounds seep through the soil and contaminate groundwater $[14,15]$. Soil particles may be attached to by these pollutants and stay over a long period, while microorganisms in the soil may break others down through degradation processes [16]. This work focused on the concentration of total petroleum hydrocarbon in soils in the immediate vicinity at the Estate and Works Departments of three universities in Port Harcourt, Rivers State, Nigeria, where heavy duty generating sets are kept as back-up electricity source in the universities.

\section{Materials and Method}

\section{Selection of Site}

Soil samples were collected from three universities in Port Harcourt, Rivers State, Nigeria. The universities are, University of Port Harcourt (UNIPORT), Rivers State University (RSU) and Ignatius Ajuru University of Education (IAUE). The samples were collected within the vicinity of the Estate and Works Departments of the various universities, where heavy duty generators are planted to supply power to the various campuses due to the inability of the National Power Generating and Distributing Companies to provide adequate power.

\section{Sample Collection}

With the aid of soil auger, soil samples were collected at a depth range of 1 to $1.5 \mathrm{~m}$ from the various sites. Four soil samples collected at random within the sites were combined together to form a 500g composite sample. The collected samples were then homogenized with the aid of a ceramic mortar and pestle plastic that was washed and dried previously. The soil samples were then kept in a thoroughly in clean plain amber bottles in order to avoid being contaminated. The soil samples were then placed in an icechest container. The collected samples were then transported to the laboratory for treatment before being analyzed for total petroleum hydrocarbons.

\section{Extraction of Soil Sample}

Analytical weighing balance was used to weigh out $10 \mathrm{~g}$ of the homogenized soil sample for extraction purposes, and then put into an amber bottle with the aid of a spatula. Addition of $5 \mathrm{~g}$ anhydrous sodium sulphate into the amber bottle was made in order to remove moisture from the homogenized soil sample and then stirred with a magnetic stirrer for thorough mixing. $300 \mu \mathrm{g} / \mathrm{ml}$ concentration of 1-chlorooctadecane was added as a standard surrogate to the soil sample and $300 \mathrm{ml}$ of dichloromethane was then added to the amber bottle containing the soil sample as the extracting solvent. The amber bottle was thoroughly corked to prevent air from entering in and a mechanical shaker was used in agitating the samples for a period of 6 hours under room temperature conditions. The agitated samples were allowed to settle gently for an interval of one-hour and filtration was made using $11 \mathrm{~mm}$ filter paper into a beaker 
that was previously washed and cleaned for that purpose and then allowed to concentrate to $1 \mathrm{ml}$ through evaporation under room temperature conditions in a fume cupboard $[17,18]$.

\section{Soil Sample Clean-Up Procedure}

The column clean-up was performed by the introduction of a glass-wool into a chromatographic column thoroughly washed, then silica gel was added into a beaker. Dichloromethane was added to the beaker containing the silica gel to make it slurry, and then introduced into the column. Sodium sulphate (anhydrous form) was then added, which was followed by n-pentane into the chromatographic column. The already concentrated sample was then mixed with cyclohexane and put into a beaker and then added into the already prepared column. Pentane was used in the eluting of the samples and then collected below the column. More pentane was being added for more elution of the sample to take place. The soil samples were evaporated to dryness after the column was rinsed with dichloromethane. The method of [19] and LAWI [18] were used in treating the soil samples.

\section{Separation and Detection of Soil Samples}

Agilent $6890 \mathrm{~N}$ Gas Chromatography-Flame Ionization Detector (GC-FID) was used to detect the level of total petroleum hydrocarbons in soils from the stations under investigation [20]. Injection of $3 \mu \mathrm{l}$ concentration of the previously clean-up sample was done with the aid of a micro-syringe into the GC-vial. The syringe was first cleansed by using blank dichloromethane to be injected through the syringe. The cleaning process of the syringe

Table 1: Level of Concentration of Total Petroleum Hydrocarbons in the Soils of the Estate and works Departments of the Universities.

\begin{tabular}{|c|c|c|c|}
\hline \multirow{2}{*}{ Carbon Length (mg/Kg) } & \multicolumn{3}{|c|}{ Universities } \\
\hline & IAUE & RSU & UNIPORT \\
\hline $\mathrm{C} 8$ & 4.42145 & - & 4.40920 \\
\hline C9 & - & - & - \\
\hline $\mathrm{C} 10$ & - & - & - \\
\hline $\mathrm{C} 11$ & 2.14677 & 2.01837 & 2.60133 \\
\hline $\mathrm{C} 12$ & 3.35384 & 3.05701 & 3.21101 \\
\hline $\mathrm{C} 13$ & 7.01018 & 5.73828 & 4.89693 \\
\hline $\mathrm{C} 14$ & 21.74394 & 16.73274 & 18.72247 \\
\hline $\mathrm{C} 15$ & 18.66803 & 14.00476 & 12.03548 \\
\hline $\mathrm{C} 16$ & 45.84241 & 12.52497 & 16.51023 \\
\hline $\mathrm{C} 17$ & 49.53566 & 19.96827 & 18.88639 \\
\hline $\mathrm{C} 18$ & 135.62842 & 99.35272 & 93.36628 \\
\hline C19 & 89.8452 & 30.02676 & 35.83295 \\
\hline $\mathrm{C} 20$ & 83.50204 & 58.11582 & 58.32146 \\
\hline $\mathrm{C} 21$ & 82.68804 & 74.39992 & 74.99342 \\
\hline $\mathrm{C} 22$ & 17.02611 & 16.30559 & 19.30957 \\
\hline $\mathrm{C} 23$ & 31.42845 & 24.50720 & 23.72050 \\
\hline $\mathrm{C} 24$ & 29.26306 & 27.34844 & 25.43832 \\
\hline $\mathrm{C} 25$ & 43.95466 & 33.11769 & 35.10964 \\
\hline
\end{tabular}




\begin{tabular}{|c|c|c|c|}
\hline C26 & 167.09702 & 14.73968 & 16.79836 \\
\hline C27 & 35.07342 & 26.98035 & 24.97821 \\
\hline C28 & 81.6706 & 15.50924 & 16.49205 \\
\hline C29 & 90.79549 & 47.22181 & 47.11380 \\
\hline C30 & 25.77430 & 25.01272 & 28.03269 \\
\hline C31 & 58.98981 & 56.10310 & 57.31005 \\
\hline C32 & 55.33079 & 49.87378 & 46.97482 \\
\hline C33 & 67.20622 & 58.85809 & 64.35609 \\
\hline C34 & 21.49957 & 22.46751 & 22.56355 \\
\hline C35 & 44.79957 & 44.84194 & 43.78499 \\
\hline C37 & 19.44003 & 25.15220 & 21.52510 \\
\hline C38 & 74.94762 & 63.06201 & 66.05310 \\
\hline C39 & 39.56833 & 31.08509 & 33.06915 \\
\hline C40 & 15.34741 & 19.24156 & 17.64758 \\
\hline Total & 11.97005 & 15.77423 & 14.87414 \\
\hline
\end{tabular}

Alinnor, et al. [23] also showed that contamination of soil by total petroleum hydrocarbons decreased with increase in depth with recorded values of 519952, 2341, and $1116.96 \mathrm{mg} / \mathrm{Kg}$ between $0.00-2.0 \mathrm{~m}$ depth which is greater on the average when compared to this work. The work of Ibezue [24], on soil samples within Gokana, Rivers State revealed total petroleum hydrocarbon concentration level of 13949.42 and $8279.35 \mathrm{mg} / \mathrm{Kg}$, which were far higher than that obtained in this work. However, values of total petroleum hydrocarbons concentrations in soils obtained by Okop, et al. (2012) were 289, 417 and 178mg/Kg for top soil, subsoil and greater depth respectively, Li, et al. [25], Adeniyi, et al. [26], were within the range of $100-500 \mathrm{mg} / \mathrm{Kg}$, were all lower than the values obtained in this study. The results of this study as shown in Table 1 , showed that accumulation of total petroleum hydrocarbons took place in all the stations and the highest value obtained in IAUE is an indication that diesel generators were used more often in IAUE than the other universities under investigation.

Further observation showed that supply of electricity by Electricity Distribution Company is in the order RSU > UNIPORT $>$ IAUE, as the level of hydrocarbons pollution has revealed. The low and non-presence of the $\mathrm{C}_{8}-\mathrm{C}_{10}$ range might be as a result of volatility, biodegradation, leaching and reactions [23], associated with the range or probably due to the use of diesel engines, since diesel range is from $\mathrm{C}_{11}$ above. The low presence of the $\mathrm{C}_{8}$ $\mathrm{C}_{10}$ range observed in IAUE and UNIPORT might have resulted from repair works on the generators during the period of study since petrol is often used in washing off grease and oil in engine parts during maintenance and servicing of heavy-duty machines. The study showed that the soil within the vicinity of the Estate and Works Departments in the Universities housing the heavyduty generators were grossly polluted since they far exceeded the required acceptable level of Environmental Guidelines and Standards for the Petroleum Industries in Nigeria (EGASPIN) [27].
The anthropogenic behavior of man was the major reason behind this high level of contamination and pollution, since it is difficult for contamination of such level by organic pollutants to occur naturally [28]. The level of total petroleum hydrocarbons contamination is a global tool used in establishing soil clean-up targets as allowed by regulatory agencies involved [29,30].

The values measured in this work has established that the total petroleum hydrocarbons concentrations in the study areas of the universities were far more than the that recommended by the national regulatory body [31]. The observations from this work will further aid the monitoring and tracking of hydrocarbon contaminants in the soils of the study area and can therefore be of great help during remediation processes within the universities' communities. This observation agreed with Makadia, et al. [32] and Pinedo, et al. [33] (Table 1). The importance of total petroleum hydrocarbons as a tool in identifying the source of pollution and contamination of the soils within the Universities' Estate and Works Departments are shown in Table 2. Useful mathematical indices and ratios such as $\mathrm{C}_{15}-\mathrm{C}_{19}$ (odd number $\mathrm{TPH}$ ), $\mathrm{C}_{18}-\mathrm{C}_{22}$ (even number TPH), low molecular weight to high molecular weight hydrocarbons $(\mathrm{L} / \mathrm{H})$, long chain hydrocarbons (LHC) to short chain hydrocarbons (SHC), average carbon chain length (ACL) and carbon preference index (CPI) were used in the identification of the origins of total petroleum hydrocarbons in the soil of the study area $[34,35]$.

The ratio of long chain hydrocarbons to short chain hydrocarbons (LHC/SHC) is used in order to assess how abundant phytoplankton or vascular plants are in the soil environment [36]. Total petroleum hydrocarbons less than or equal to $\mathrm{C}_{26}$ are known as short chain hydrocarbons while those greater $\mathrm{C}_{26}$ are referred to as long chain hydrocarbons. The LHC used in this calculation were $\mathrm{C}_{27}+\mathrm{C}_{29}+\mathrm{C}_{31}$ while SHC were $\mathrm{C}_{15}+\mathrm{C}_{17}+\mathrm{C}_{19}$. LHCs originates from vascular plants while SHCs originates from plankton and 
benthic algae [36]. The results obtained from this study varied from 1.8461 to 2.03603 with an average value of 1.71970 in the soils affected by total petroleum hydrocarbons due to heavy-duty diesel engines used to supply electricity. The ratio between 0.21 0.80 range establishes that phytoplankton dominates, 2.38-4.33 is an indication of mixed origin, but when the ratio is greater than 4 , there is the dominance of terrestrial plant waxes [37]. The results obtained was an indication that the source of pollution in the soils might be from mixed origin.

The $\mathrm{L} / \mathrm{H}$ is a ratio that establishes the quantity of low molecular weight total petroleum hydrocarbons $\left(\mathrm{C}_{15}-\mathrm{C}_{20}\right)$ compared to the high molecular weight hydrocarbons $\left(\mathrm{C}_{21}-\mathrm{C}_{40}\right)$. It is an important instrument for understanding the hydrocarbons sources in the environments [36,38]. The results obtained in Table 2 showed that the $\mathrm{L} / \mathrm{H}$ ratio was within $0.33558-0.4123$ range with an average value of 0.36372 . The summation of the ratio of $\mathrm{L} / \mathrm{H}$ when less than 1 implies hydrocarbons from higher plants, marine animals and water bacteria, plankton and petroleum sources while ratio greater than 2 is an indication of fresh oil. The study revealed that the $\mathrm{L} / \mathrm{H}$ ratio was $<1$, therefore the source may be due to hydrocarbons from higher plants. Considering the distribution pattern of total petroleum hydrocarbons in the soils under study as shown in Table 2, ranged from 953.11949 to $1475.56904 \mathrm{mg} / \mathrm{Kg}$, with an average of $1132.20913 \mathrm{mg} / \mathrm{Kg}$ in the samples analyzed. This clearly indicated that specific total petroleum hydrocarbons were present.

The high presence of $\mathrm{C}_{16}, \mathrm{C}_{18}$, and $\mathrm{C}_{20}$ was an indication of hydrocarbons of anthropogenic origin while that from microbial biogenic origin is visible with the presence of $\mathrm{C}_{12}$ and $\mathrm{C}_{14} . \mathrm{C}_{15}, \mathrm{C}_{17}$ and $\mathrm{C}_{19}$ were also present, was an indication of phytoplankton and algae of soil biogenic origin $[39,40]$. The dominance of even number hydrocarbons over odd number hydrocarbons was an indication of anthropogenic origin while that due to $\mathrm{C}_{25}-\mathrm{C}_{35}$ hydrocarbons was an input from biogenic sources (terrestrial and vascular plants) $[41,42]$. The determination of $\mathrm{C}_{31} / \mathrm{C}_{19}$ ratio of total petroleum hydrocarbons in the soils of the studied areas was to ascertain hydrocarbons of terrestrial origin to those of marine origin. $\mathrm{C}_{31}$ hydrocarbons is an indication of terrestrial biogenic origin while $\mathrm{C}_{19}$ hydrocarbons provides information on the presence of biogenic origin [36]. $\mathrm{C}_{31} / \mathrm{C}_{19}$ values more than 0.4 is an indication that the total petroleum hydrocarbons present were not from marine origin as observed by Ahmed, et al. [38]. The $\mathrm{C}_{31} / \mathrm{C}_{19}$ hydrocarbon ratio obtained in this work ranged between 0.65657 to 1.86844 with stations average of 1.3748 which indicated that the hydrocarbon pollution is terrestrial in nature. This assertion agreed with Adeniji, et al. [42].

The carbon preference index (CPI), measures the ratio of odd to even numbered hydrocarbons and is calculated mathematically as:

$$
\left.C P I_{25-35}=0.5\left[\left(C_{25}-C_{33} / C_{24}-C_{32}\right)\right]+\left[\left(C_{25}-C_{33}\right) / C_{26}-C_{34}\right)\right]
$$

This index is a useful assessment to note the dominance of natural total petroleum hydrocarbons over anthropogenic hydrocarbons [44]. CPI values greater than 1 (ranging from 3-10) is an indication of biogenic materials such as epicuticular waxes in algae or terrestrial vascular plants and a dominance of odd numbered hydrocarbons. When CPI values are close to 1 , it suggests the possibility of hydrocarbons from petrochemical source [45]. Observation from Table 2 revealed that CPI values ranged between 1.04594-2.60460 with an average value of 2.08124, which is an indication of aliphatic hydrocarbons from natural origin.

The average carbon length (ACL) is calculated using the relation $[46,47]$.

$$
\text { ACL value }=\frac{25\left(n C_{25}\right)+27\left(n C_{27}\right)+29\left(n C_{29}\right)+31\left(n C_{31}\right)+33\left(n C_{33}\right)}{C_{25}+C_{27}+C_{29}+C_{31}+C_{33}}
$$

This is a useful index in evaluating odd carbon dominance per molecule in environmental samples. The ratio helps in establishing the link between higher plants and normal alkanes with the environment. Non-polluted sites give constant values and the values depletes when an area is polluted with petroleum hydrocarbons [48]. The results obtained from the soil under study were within 29.47578 to 29.79370 with an average of 29.66491 . The results showed that the three stations were operated under the same conditions and the origin of hydrocarbon pollution in the areas were basically anthropogenic. The results showed higher values which was an indication of heavier petroleum hydrocarbons. This is corroborated by Adeniji, et al. [43] (Tables 2 \& 3).

Table 2: Diagnostic Ratios and Source Identification of TPH in the Soils of the Estate and Works Departments of the Universities.

\begin{tabular}{|c|c|c|c|c|}
\hline \multirow{2}{*}{ Parameter } & \multicolumn{3}{|c|}{ Universities } & \multirow{2}{*}{ Mean } \\
\cline { 2 - 4 } & IAUE & RSU & UNIPORT & 1132.20913 \\
\hline $\mathrm{TPH}$ & 1475.5604 & 953.11949 & 968.93886 & 95.60153 \\
\hline $\mathrm{C}_{15}-\mathrm{C}_{19}$ (Odd Number TPH $)$ & 156.04998 & 63.99979 & 66.75482 & 19364267 \\
\hline $\mathrm{C}_{18}-\mathrm{C}_{22}($ Even Number TPH $)$ & 236.15657 & 13.77413 & 170.99731 & 496.81075 \\
\hline $\mathrm{C}_{25}-\mathrm{C}_{35}$ & 692.19191 & 394.72609 & 403.51425 & 1.71970 \\
\hline $\mathrm{LHC} / \mathrm{SHC}$ & 1.18461 & 2.03603 & 1.93847 & 0.36372 \\
\hline $\mathrm{L} / \mathrm{H}\left[\left(\mathrm{C}_{15}-\mathrm{C}_{20}\right) /\left(\mathrm{C}_{21}-\mathrm{C}_{40}\right)\right]$ & 0.41723 & 0.33835 & 0.33558 & 1.3748 \\
\hline $\mathrm{C}_{31} / \mathrm{C}_{19}$ & 0.65657 & 1.86844 & 1.59937 & 2.08124 \\
\hline $\mathrm{CPI}$ & 1.04594 & 2.59318 & 2.60460 & 2.08124 \\
\hline $\mathrm{ACL}$ & 29.47578 & 29.72524 & 2.60460 & \\
\hline
\end{tabular}


Table 3: Molecular Ratios and Indices for the Identification of Total Petroleum Hydrocarbons Source in the Soil.

\begin{tabular}{|c|c|c|c|c|c|}
\hline \multirow{2}{*}{ Ratios/Indices } & \multicolumn{3}{|c|}{ Biogenic Origin (Plants/Microorganisms) } & \multicolumn{2}{|c|}{ Petrochemical/Anthropogenic Origin } \\
\hline & Terrestrial & Mixed & Marine & Degraded Oil & Fresh Oil \\
\hline CPI & $<1$ & - & $\sim 1$ & $\sim 1$ or $<1$ & - \\
\hline LMW/HMW & $>0.4$ & - & $\sim 1$ & $\sim 1$ & $>2$ \\
\hline $\mathrm{nC} 31 / \mathrm{nC} 19$ & $>4$ & - & $\leq 0.4$ & - & - \\
\hline LHC/SHC & & $2.38-4.33$ & $0.21-0.80$ & - & - \\
\hline ACL & \multicolumn{3}{|c|}{ Higher and Constant (close range) } & \multicolumn{2}{|c|}{ Depletes and fluctuates (wide range) } \\
\hline
\end{tabular}

\section{Conclusion}

The present study evaluated the presence of total petroleum hydrocarbons in the soils from the Estate and Works Departments, where heavy-duty generators are mounted and found out that there was pollution of the soils as a result of the generator usage. The soil was polluted with hydrocarbons range of $C_{11}$ to $C_{40}$ which was an indication the generators actually used diesel and lubricating oil in their daily operation works. The evaluation of different ratios and indices to ascertain the pollution sources of total petroleum hydrocarbons in the soils from the universities' power stations. The results showed that the major source of hydrocarbons in the soils was anthropogenic. The relevant authorities should therefore put in place health institutions that can easily be assessed by the workers in the generator houses and effective remediation processes be put in place immediately or restore proper electricity through the national grid.

\section{References}

1. (2009) Department for Environment, Food and Rural Affairs (DEFRA) Soil strategy for England supporting evidence paper.

2. Edori ES, Kpee F (2019) Total petroleum hydrocarbon concentration in surface water from Taylor Creek, Rivers State, Nigeria. Chemistry Research Journal 4(5): 1-8.

3. Adipah S (2019) Introduction of petroleum hydrocarbons contaminants and its human effects. Journal of Environmental Science and Public Health 3(1): 1-9.

4. (2011) US Environmental Protection Agency (USEPA). Crude and petroleum products.

5. Daraei H, Mittal A, Noorisepehr, Daraei F (2013) Kinetic and equilibrium studies of adsorptive removal of phenol onto eggshell waste. Environmental Science and Pollution Research 20: 4603-4611.

6. Veellu R (1989) Petroleum hydrocarbon along the coastal area of Port Dickson. Petranika 12(3): 349-355.

7. Ahmed F, Anm F (2018) A review on environmental contamination of petroleum hydrocarbons and its biodegradation. International Journal of Environmental Science and Natural Resources 11(3): 63-69.

8. Mohammadi L, Rahdar A, Bazrafshan E, Dahmardeh H, Susan ABH, et al. (2020) Petroleum hydrocarbon removal from wastewaters: A Review. Processes 8(4): 447.

9. Meindinyo RK, Agbalabga FO (2012) Radioactivity concentration and heavy metal assessment of soil and water in and around Imirigin oil field, Bayelsa State, Nigeria. Journal of Environmental Chemistry and Ecotoxicology 4(2): 29-34.

10. Ogboi E (2012) Heavy metal movement in crude oil polluted soil in Niger Delta Region. Journal of Agriculture and Veterinary Sciences 4: 71-78.
11. Nwankwo IL, Ekeocha NE, Ikoro DO (2015) Evaluation of deviation of some soil contamination indicators due to oil spill in Akinima, Rivers State. Scientific Research Journal 3(7): 19-24.

12. Odu CTI, Esuruoso ON, Oguwale JA (1985) Environmental study of Nigeria Agip Oil Company Operational Area. Nigeria Agip Oil Company Ltd Lagos.

13. Ojimba TP, Iyagba AG (2012) Effects of crude oil pollution on horticultural crops in Rivers State, Nigeria. Global Journal of Science Frotier Research Agriculture and Biology 12(4): 37-44.

14. Laskova T, Zabukas V, Viatiekunas P (2007) Influence of meteorological conditions on volatile organic spread in the atmospheric boundary layer. Journal of Environmental Engineering and Landscape Management 15(3): 135-143.

15. Paulauskiene T, Zabukas V, Viatiekunas P (2009) Investigation of volatile organic compounds (VOC) emission in oil terminal storage tank parks. Journal of Environmental Engineering and Landscape Management, 17(2): 81-88.

16. Research Triangle Institute (1999) Toxicological profile for total petroleum hydrocarbons (TPH). Prepared for U.S. Department of Health and Human Services.

17. Saari E, Peramaki P, Jalonen J (2007) A comparative study of solvent extraction total petroleum hydrocarbons in soil. Microchim Acta 158(8): 261-268.

18. Laboratory Analytical Work Instruction (LAWI) (2011) For the determination of total petroleum hydrocarbon in soil /sediment/sludge in Gas Chromatography. Published by Fugro (Nig). Ltd. 3: 9.

19. Maioli OL, Rodrigues CK, Knoppers BA, Azevedo D (2011) Distribution and sources of aliphatic and polycyclic aromatic hydrocarbons in suspended particulate matter in water from two Brazilian estuarine systems. Cont Shelf Res 31(10): 1116-1127.

20. Cortes JE, Suspes A, Roa S, González C, Castro HE (2012) Total Petroleum Hydrocarbons by Gas Chromatography in Colombian Waters and Soils. American Journal of Environmental Science 8(4): 396-402.

21. Department of Petroleum Resources (DPR) (2019) Environmental Guidelines and Standards for the Petroleum Industry in Nigeria.

22. Udume OA, Abu GO (2019) Risk study of hydrocarbon impacted surficial soil at the heavy-duty diesel generator plant in Delta Park, University of Port Harcourt, Nigeria. Journal of Advances in Microbiology 18(4): 1-12.

23. Alinnor IJ, Ogukwe CE, Nwagbo NC (2014) Characteristic level of total petroleum hydrocarbon in soil and groundwater of oil impacted area in the Niger Delta Region, Nigeria. Journal of Environmental and Earth Sciences 4(23): 188-194.

24. Ibezue VC (2013) Effects of fossil extraction in Gokana environment, Ogoni land, Nigeria. $2^{\text {nd }}$ International Conference on Energy Systems and Technologies, Cairo, Egypt.

25. Li H, Zhang Y, Zhang CG, Chen GX (2005) Effect of petroleum containing wastewater irrigation on bacterial diversities and enzymatic activities in a paddy soil irrigation area. Journal of Environmental Quality 34(3): 1073-1080. 
26. Adeniyi AA, Afolabi JA (2002) Determination of total petroleum hydrocarbon and heavy metals in soils within the vicinity of facilities handling refined petroleum products in Lagos metropolis. Environment International 28(1-2): 79-82.

27. Department of Petroleum Resources (DPR) (2002) Environmental Guidelines and Standards for the Petroleum Industry in Nigeria (EGASPIN). Revised Edition, pp. 314

28. Birke M (2007) Joint interpretation using statistical methods In: Lange G and Knodel K (Edi.): Springer, Berlin.

29. (2005) Presidency Ministry (Spain). Royal decree $9 / 2005$ of $14^{\text {th }}$ January which establishes a list of potentially soil contaminating activities and criteria and standards for declaring that sites are contaminated. Official State Bulletin 15/2005 Presidency Ministry, Madrid Spain in Spanish, pp. 1833-1843.

30. (2012) VROM (Dutch Ministry of Housing, Spatial Planning and The Environment Soil remediation circular 2009, Staats courant 3 April 2012 No. 6563. Ministry of Housing, Spatial Planning and The Environment. The Hague.

31. Pinedo J, Ibanez R, Gomez P, Ortiz I (2010) Risk assessment of off-site polluted soils due to hydrocarbon storage in Cantabria Region. Technical Communication on $10^{\text {th }}$ National Environmental Congress (CONAMA10), Madrid Spain (in Spanish).

32. Makadia TH, Adetutu EM, Simons KL, Jardine D, Sheppard PJ, et al. (2011) Re-use of remediated soils for the bioremediation of waste sludge. Journal of Environmental Management 92(3): 866-871.

33. Pinedo J, Ibanez R, Lijzen JPA, Irabien A (2013) Assessment of soil pollution based on total petroleum hydrocarbons and individual oil substances. Journal of Environmental Management 130: 72-79.

34. Sakari M, Ting LS, Houng LY, Lim SK, Tahir R, et al. (2012) Urban effluent discharge into rivers; a forensic Chemistry approach to evaluate the environmental deterioration. World Applied Sciences Journals 20(9): 1227-1235

35. Duan Fengkui F, He K, Liu X (2010) Characteristics and source identification of fine particulate n-alkanes in Beijing China. Journal of Environmental Sciences 22(7): 998-1005.

36. Fagbote OE, Olanipekun EO (2013) Characterization and sources of aliphatic hydrocarbons of the sediments of River Oluwa at Agbaba Butimen deposit area, Western Nigeria. Journal of Science Research and Report 2(1): 228-248.

37. Bianchi TS (2007) Biogeochemistry of Estuaries, $6^{\text {th }}$ (Edn.), Oxford University Press: Northants, UK, pp. 20-720.

\section{ISSN: 2574-1241}

DOI: $10.26717 /$ BJSTR.2020.30.004894

EDORI Enize Simeon. Biomed J Sci \& Tech Res

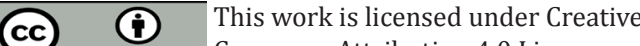

Commons Attribution 4.0 License

Submission Link: https://biomedres.us/submit-manuscript.php
38. Ahmed OE, Mahmoud SA, Mousa AE (2015) Aliphatic and poly-aromatic hydrocarbons pollution at the drainage basin of Suez Oil Refinery Company. Current Science International 4(1): 27-44.

39. Al Baldawin IA, Abdullah SRS, Anuar N, Suja F, Mushrifah I (2015) Phytodegradation of total petroleum hydrocarbon (TPH) in dieselcontaminated water using Scirpus grossus. Ecological Engineering 74: 463-473.

40. Harji RR, Yvenat A, Bhosle NB (2008) Sources of hydrocarbons in sediments of the Mandovi estuary and the Marmugoa harbour, west coast of India. Environment International 34(7): 959-965.

41. Gao X, Chen S (2008) Petroleum pollution in the surface sediments of Daya Bay, South China, reveal by Chemical Fingerprinting of aliphatic and alicyclic hydrocarbons. Estuarine, Coastal and Shelf Science 80(1): 95-102.

42. Adeniji AO, Okoh 00, Okoh AI (2017) Petroleum hydrocarbon profiles of water and sediment of Algoa Bay, Eastern Cape, South Africa. International Journal of Environmental Research and Public Health 14(10): 1263.

43. Adeniji AO, Okoh 00, Okoh AI (2017) Petroleum hydrocarbon fingerprints of water and sediment samples of Buffalo River Estuary in the Cape Province, South Africa. Journal of Analytical Methods in Chemistry 2017: 2629365.

44. Wu Y, Zhang J, Mi TZ, Li B (2001) Occurrence of n-alkanes and polycyclic aromatic hydrocarbons in the core sediments of the Yellow sea. Marine Chemistry 76(1-2): 1-15.

45. Michelle A, Carlos AB, Mrcia CB, Cesar CM (2014) Sedimentary biomarkers along a contamination gradient in a human-impacted subestuary in Southern Brazil, A multi-parameter approach based on spatial and seasonal variability. Chemisphere 103: 156-163.

46. Kiran R, Krishna VVJG, Naik BG (2015) Can hydrocarbons in coastal sediment be related to terrestrial flux? A case study of Godavari river discharge (Bay of Bengal). Current Science 108(1): 96-100.

47. Wang M, Zhang W, Hon J (2015) Is average chain length of plant lipids a potential proxy for vegetation, environment and climate changes? Biogeosciences Discuss 12: 5477-5501.

48.Jeng WL (2006) Higher plant n-alkane average chain length as an indicator of petrogenic hydrocarbon contamination in marine sediments. Marine Chemistry 102(3-4): 242-251.

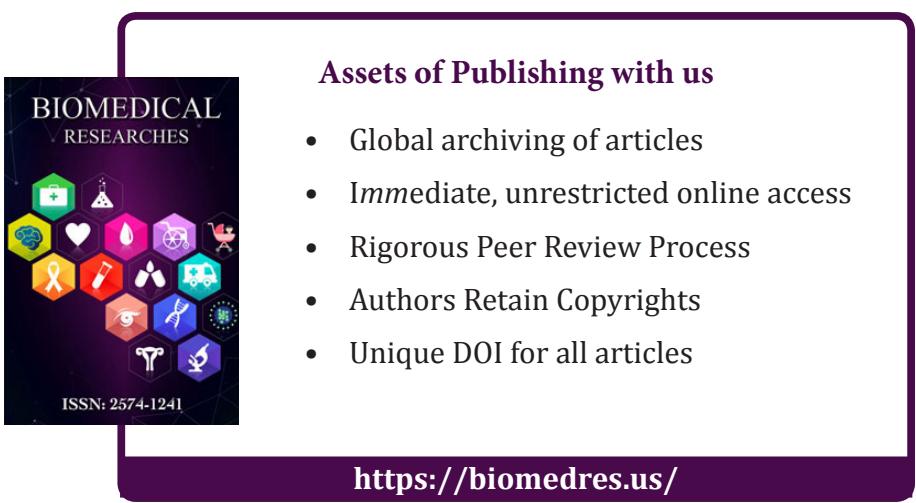

Copyright@ EDORI Enize Simeon | Biomed J Sci \& Tech Res | BJSTR. MS.ID.004894. 